\title{
Tourism Life Cycle Assessment (LCA): Proposal of a New Methodological Framework for Sustainable Consumption and Production
}

\author{
Camillo De Camillis ${ }^{1,2}$, Paul Peeters ${ }^{3}$, Luigia Petti ${ }^{4}$ and Andrea Raggi ${ }^{4}$ \\ 'Dipartimento di Scienze, Università degli Studi "G. d'Annunzio", Pescara \\ ${ }^{2}$ European Commission, Joint Research Centre, IES, Ispra* \\ ${ }^{3}$ Center for Sustainable Transport and Tourism, NHTV Breda \\ University of Applied Sciences, Breda, \\ ${ }^{4}$ Dipartimento di Economia, Università degli Studi "G. d'Annunzio", Pescara \\ 1,2,4 Italy \\ ${ }^{3}$ The Netherlands
}

\section{Introduction}

International tourism has become an important part of modern life styles, while it is now one of the largest and fastest growing economic sectors worldwide, even though it appears vulnerable to the occasional economic or global socio-political shocks over the last decade (UNWTO, 2010). Tourism's contribution to the worldwide gross domestic product (GDP) is estimated at some 5\% (ibid). However, this strong growth also implies an increase of undesired environmental impacts. Tourism is globally responsible for $5 \%$ of all carbon dioxide emissions, the most important greenhouse gas causing climate change (UNWTO UNEP WMO, 2008). However, in terms of radiative forcing, the direct measure for contribution to climate change, tourism could even have a share of up to $12.5 \%$ (Scott et al., 2010). Also, the greenhouse gas emissions of tourism are estimated to grow at a rather large rate, although global emissions should be reduced up to $80 \%$ by 2050 (e.g. Scott et al., 2010). Finally, it has been shown that the eco-efficiency - the economic contribution per ton emissions - of tourism is rather low (Gössling et al., 2005). These data contradict the rather common view among many researchers in the past, according to which tourism is a low environmental impact industry (McCrory, 2006). Now, it is a shared concept that tourist activities are strongly related to the environment, since, on the one hand, the natural environment itself may be considered as a major input resource to the processes of tourism industries and, on the other hand, the development of tourism as a mass industry may severely increase its overall impact on the environment (Raggi \& Petti, 2006a; Romeril, 1989).

\footnotetext{
* The views expressed in the article are personal and do not necessarily reflect an official position of the European Commission.
} 
Given the predictions of an increased role of tourism industries in the world economy, the environmental aspects of, and impacts generated by tourist activities should be accurately considered according to a Life Cycle Thinking (LCT) perspective. This concept has been extensively advocated as the proper way of addressing the challenges linked with sustainable development, and, in particular, with those measures for enhancing sustainable consumption and production. In the framework of sustainable development policies, the "Sustainable Consumption and Production and Sustainable Industrial Policy (SCP) Action Plan" (European Commission, 2008) is a building block in the EU.

In line with this policy, a wide range of environmental instruments have been developed for assessment and labelling/certification purposes of travel and tourist services. This ongoing proliferation of different initiatives shows a high degree of diversity in terms of scope, assessment methodologies and means of communication. Although this proliferation reflects the vast variety of travel and tourist products as well as their complicated nature when it comes to the assessment of the environmental performance, these environmental instruments seem to suffer from a lack of integration and standardisation or quality control. This situation has the potential to confuse or even mislead travellers and the stakeholders within the industry.

This implies three questions we seek to answer in this chapter. Firstly, what environmental instruments and initiatives are currently supporting the application of the European Sustainable Consumption and Production (SCP) Action Plan in the travel and tourism industry? Secondly, what are their key characteristics and how do they stand in relation to Life Cycle Assessment (LCA) principles? And thirdly, how can these instruments be combined into a general framework capable to render this industry low carbon and more sustainable from an environmental point of view?

In this chapter, the topic will be introduced in the first sections. In particular, the key concepts of LCT and its supported methodologies are illustrated in section 2. More information on the application steps of the LCT-oriented environmental assessment methodology (i.e. LCA) is outlined in section 3. The meaning of life cycle in the tourism sector will be investigated in section 4 . In order to answer the research questions, a review of the existing environmental instruments in the European travel and tourism industry was made. The review method applied and overview of the existing instruments and initiatives are the subjects of section 5 and 6, respectively. Possible methodological improvements are also outlined for each instrument and initiative in section 6. By proposing linkages among the existing instruments, we finally present in section 7 a new methodological framework for sustainable consumption and production in the travel and tourism sector. This framework includes, inter alia, a new platform enabling travellers to plan eco-friendly holidays in Europe.

\section{Life Cycle Thinking: Key concepts and methodologies}

Life Cycle Thinking (LCT) is a quantitative approach which aims at taking into account all life cycle phases of a product (e.g. extraction of the raw materials, pre-production processes, production, consumption, end-of-life) in a broad range of methodologies and instruments for sustainability assessment and management (Azapagic \& Clift, 1999; European Commission, 2010; Finnveden et al., 2009; Heiskanen, 2002; Hunkeler \& Rebitzer, 2005; 
Maxwell et al., 2006; Rebitzer \& Buxmann, 2005; Rebitzer et al., 2004). Although LCT was initially conceived for products, it can also fit for services (De Camillis et al., 2008; Graedel, 1997; Petti \& Tontodonati 2002; Raggi et al., 2008a, 2008b; Raggi \& Petti 2006a; Raggi et al., 2005; Rosenblum et al., 2000). One of the major strengths of LCT is its comprehensiveness. This characteristic makes LCT a unique perspective to detect potential shifts of economic, environmental and social burdens from one phase of the life cycle to another, from a certain geographical area to another, and from one sustainability issue to another (European Commission, 2007; Finnveden et al., 2009).

Several LCT-based methodologies and instruments for sustainable development have already been developed so far. One of the most known is Life Cycle Assessment (LCA), a methodology to assess the potential environmental impact of a product/service in terms of individual environmental impact categories (e.g. global warming, human and environmental toxicity, natural resource depletion, ozone layer depletion, summer smog, etc.) and along its life cycle phases (Pennington et al., 2004; Rebitzer et al., 2004). In fact, all activities involved in a certain product's life cycle result in environmental impacts that in most cases are negative due to consumption of resources, and emissions of harmful substances into the natural environment. The LCA methodology has continued to develop and has become to some extent mature during the last decades. From the first conceptualisations (Heijungs et al., 1992; Consoli et al., 1993), LCA is now an internationally standardised methodology (ISO 14040:2006; ISO 14044:2006) recognised by the European Commission (2003) as the best tool for assessing the life cycle environmental impacts of products. While general guidelines for LCA have been issued by the European Commission (2010), many initiatives have been developing ad hoc sector- and product-specific methodologies.

Besides LCA, ecodesign is another LCT-based method. Ecodesign - also generally known as Design for Environment (DfE) or Life Cycle Design (LCD) - aims at preventing pollution by supporting product designers during the entire development process of products/services with regard to environmental choices (Fitzgerald et al., 2007; Vezzoli \& Sciama, 2006). This method has been also standardised (ISO/TR 14062:2002).

Regarding environmental labelling, three types of options are regulated in international standards (ISO 14020:2000). In this context, considerations from LCA case studies are to be taken into account in setting up criteria for Type I environmental labels (ISO 14024:1999), such as e.g. the EU eco-label. A closer reference to LCA is found in those performanceoriented schemes enabling to come up with Type III environmental declarations (14025:2006), such as e.g. the Environmental Product Declaration (EPD) scheme (EPD, 2011). In these schemes, LCA is the methodology chosen for calculating the environmental performance of products. Finally, findings from LCA case studies might be used for selfdeclared claims, or Type II environmental labels (ISO 14021:1999).

In addition to product labelling options, pieces of information from LCA studies may be used for setting up and maintaining the Environmental Management Systems of those organisations certified or on the way to be certified according to ISO 14001:2004 or EMAS. Equally, findings from LCA case studies may be used for Integrated Management Systems (PAS 99:2006). 
Regarding the economic pillar of sustainability, Life Cycle Costing (LCC) is the reference methodology to investigate costs along the life cycle of products and services (Krozer, 2008; Norris, 2001; Rebitzer \& Hunkeler, 2003; Rebitzer \& Seuring, 2003; Spengler \& Stolting, 2008). Recently, significant efforts to create an LCT-based methodology to assess some social issues have been made by several researchers (Grießhammer et al., 2006; Hauschild et al., 2008; Hunkeler, 2006; Jørgensen et al., 2008; Weidema, 2005; UNEP, 2009). Yet, if compared with the current maturity level of LCA, we must admit that a Societal LCA is still in its infancy. Finally, an overarching LCT-methodology to assess the overall performance of products against the issues related to the three dimensions of sustainability has been conceived by Kloepffer (2008).

\section{Life Cycle Assessment: Stepwise application}

According to ISO 14040:2006 and ISO 14044:2006, the procedure to apply LCA is composed of four steps: goal and scope definition, Life Cycle Inventory analysis (LCI), Life Cycle Impact Assessment (LCIA), and Life Cycle Interpretation.

The goal and scope of an LCA study identifies, inter alia, the objectives and provides a comprehensive description of the system analysed in terms of "functional unit" and "system boundaries". According to ISO 14044:2006, a "functional unit" is a quantified performance of a product/service system for use as a reference unit of the analysis, and "system boundaries" are unit processes linked each other to perform one or more defined functions. In addition to this, the environmental impact categories and assessment methods are selected in this LCA step according to the purpose of the study.

Right after the goal and scope definition step, LCA practitioners compile an inventory of the environmental loads potentially occurring along the product life cycle phases. These environmental loads basically consist of: consumption of resources, waterborne and airborne emissions, releases into the soil, and waste streams. In this context, such an inventory is called Life Cycle Inventory (LCI). Collecting and elaborating data in LCIs, and fine-tuning LCIs form the second LCA application step called Life Cycle Inventory analysis (LCI).

On the basis of the LCI of the product system analysed, practitioners run the Life Cycle Impact Assessment step (LCIA) to come out with indicators expressing the potential environmental performance of the overall system analysed. More specifically, LCIA includes the following steps: associating environmental loads to the selected impact categories (classification step); calculating figures of the impact category indicators selected in the goal and scope definition (characterization step).

Besides the above-mentioned steps, the following steps are optional:

- normalization step - the results of the characterization step are normalised to certain reference values (e.g. average environmental pressure of a typical European citizen);

- grouping - normalised results are sorted according to the characteristics of the impact categories (e.g. global versus regional scale) or/and ranked according to their relevancy;

- $\quad$ weighting step - normalised results are weighted by some importance scores associated to each environmental issue by a certain body. 
Finally, the Life Cycle Interpretation step aims to evaluate the outputs of the LCI and the LCIA steps along the LCA application procedure. This step basically comes up with considerations in relation to the goal and scope of the study, highlights the study limitations and provides some conclusions.

\section{Tourism Life Cycle Assessment in a nutshell}

According to a preliminary survey on the use of LCA in the tourism industry (Raggi et al., 2005; Raggi \& Petti, 2006b), LCA is still uncommon within the tourism industry and for researchers in the field of Sustainable Tourism (Bramwell \& Lane, 2008; Hunter and Shaw, 2007). In order to gain a better understanding of the reasons for such a limited diffusion of LCA and to evaluate the need of specific LCA guidelines for the tourism sector, a critical review of the existing LCA case studies in the sector was carried out by De Camillis et al. (2010a). Furthermore, a case study was conducted on the services provided by an Italian hotel by De Camillis et al. (2010b). In the following section the findings of such efforts are reported to highlight the object of tourism LCA studies, and what life cycle means in this context.

\subsection{Identifying the object of the analysis: The tourist product}

According to the United Nations World Tourism Organization (UNWTO, 2008), "tourism comprises the activities of persons travelling to and staying in places outside their usual environment for not more than one consecutive year for leisure, business and other purposes". Even if in the scientific community there is no general consensus on the definition of tourism as a distinct industry (Leiper, 2008; Chadwick, 1994), it can be argued that tourism is a conglomerate of products distinguishable from other industries (Lew et al., 2004). In fact, tourism output is not a simple product but, rather, a wide range of goods and services interacting to fulfil a tourist experience that comprises both tangible parts (e.g. hotel, restaurant, airline) and intangible aspects (e.g. sunset, scenery, mood) (Debbage \& Daniels, 1998). The actual purchase and consumption/production of tourist services (e.g. airline ticket, meal, admission ticket) may often be incidental to "non-market" activities, such as independent sightseeing, hiking, or sunbathing (Lew et al., 2004). According to Judd (2006), the actual product of tourism is the tourist's experience which is generated by several social and economic actors. Middleton (1989) observes that the term "tourist product" is used at two different levels: the "specific" level (i.e. a discrete product offered by a single business, such as a sightseeing tour or an airline seat) and the "total" level (i.e. the complete experience of a tourist from the time one leaves home to the time one returns). From these considerations, it can be deduced that a tourist's experience is the outcome of a tourist product at a "total" level. Such a product can be seen as a system whose components (products and services) are the tourist products at a "specific" level, which are provided by different actors and may be incidental to "non-economic" activities.

Such actors can vary according to the specific forms of tourist experience concerned (e.g. coastal, urban, cultural, winter, rural). If a tourism form is considered to be a type of tourist experience commoditisation (Graburn, 2004), or in other words a tourist product at a "total" level, several categories of tourist operators can be identified for each tourism form. An inventory of tourist products in the context of certain tourism forms have been created by De Camillis et al. (2010d). For instance, those services delivered by the following organisations can be indexed as tourist products of the cultural tourism form: museum, art 
gallery, exhibition, theatre, concert hall, fair, souvenir shop, tourist organisations involved in sightseeing and guided tours, restaurant, fast food, snack bar.

Apart from the actors mentioned additionally some intermediaries are involved in the tourism production and distribution. Buhalis and Laws (2001) recognise three different types of intermediaries, i.e. outgoing travel agencies (retailers), tour operators (wholesalers) and incoming travel agencies based at destinations (handling). In particular, an outgoing travel agency serves as sales channel for tourist specific activities and wholesalers, generally transport tickets, accommodations and packages from tour operators. Tour operators buy individual tourist services (e.g. transport and accommodation) from their suppliers (e.g. carriers and hotels) and assemble them into holiday packages (Ujma, 2001). Finally, incoming travel agencies plan tour packages on a destination level and act as intermediary between tour operator and specific tourist activities (Buhalis \& Laws, 2001), but also sell to individual tourists that do not travel through a tour operator. Indeed, nowadays, also thanks to the Internet, travellers may buy various transport and tourist products at a "specific" level directly from producers or through intermediaries. Tourists also often use various distribution channels for one holiday. For example, they could use an outgoing travel agent for a 'seat only' charter product, and autonomously book accommodation, restaurants and other tourist services (Buhalis \& Laws, 2001).

\subsection{Understanding the life cycle of tourist products}

From the previous section we learnt that tourism is a complicated system due to the large number of goods and supporting services involved in it. Furthermore, describing the sector is complicated as, scientifically, there is an on-going debate about the definition of tourism. Therefore, applying LCA to calculate the environmental performance of tourist products is often problematic. In particular, these drawbacks have major implications in the "goal and scope definition" step.

As far as holidays are concerned, the boundary of the system to be analysed has been set up in a similar manner across LCA case studies (Chambers, 2004; Corsico, 2007; Sisman, 1994; UK CEED, 1998), ecological footprint studies (Hunter \& Shaw, 2007; Peeters \& Schouten, 2005), and researches on greenhouse gas (GHGs) emissions (Becken \& Hay, 2007; Peeters et al., 2009; UNWTO UNEP WMO, 2008). In particular, Chamber's "door to door" approach (Chamber, 2004), which includes all steps from departure to return back home, was adopted in many cases. Still, the system boundaries of an entire holiday should be defined on a caseby-case basis by considering a tourist experience life cycle (see Figure 1). According to Middleton (1989), a tourist experience generally starts, right after a process of information acquisition, with a booking phase. Before departure, a number of pre-departure activities may take place (e.g. vaccinations, purchase or rental of goods - e.g. clothes - for the holiday). The transport phase includes all movements carried out by tourists from departure to their return home. At destinations, accommodations receive guests for one or more nights, restaurants offer food services and leisure enterprises offer tourist activities. Public services and other supporting services should also be considered to be part of the tourist experience. After the return at home, a final phase includes all the activities to restart the everyday life.

Even if the tourist experience life cycle presented in Figure 1 can be a useful template to study some tourism forms, further considerations are needed for package holidays. In fact, travel agencies and tour operators may be found quite similar to manufacturing companies. 
Both these tourist operators and manufacturers assemble "specific" products as components of "total" branded new products. Like those manufacturing companies which are asked to be in line with the principle of Extended Producer Responsibility (EPR ${ }^{1}$, travel agencies and tour operators are also increasingly responsible for the impacts of all components of the tourist products they sell, including use of raw materials, processing and production, as well as impacts from transport and distribution (Tapper \& Font, 2004). In other words, all "specific" tourist products that contribute to the tourist experience should be included in the system boundaries whenever the assembled product named package holiday is studied.

1. Pre-departure activities:

Information acquiring, booking

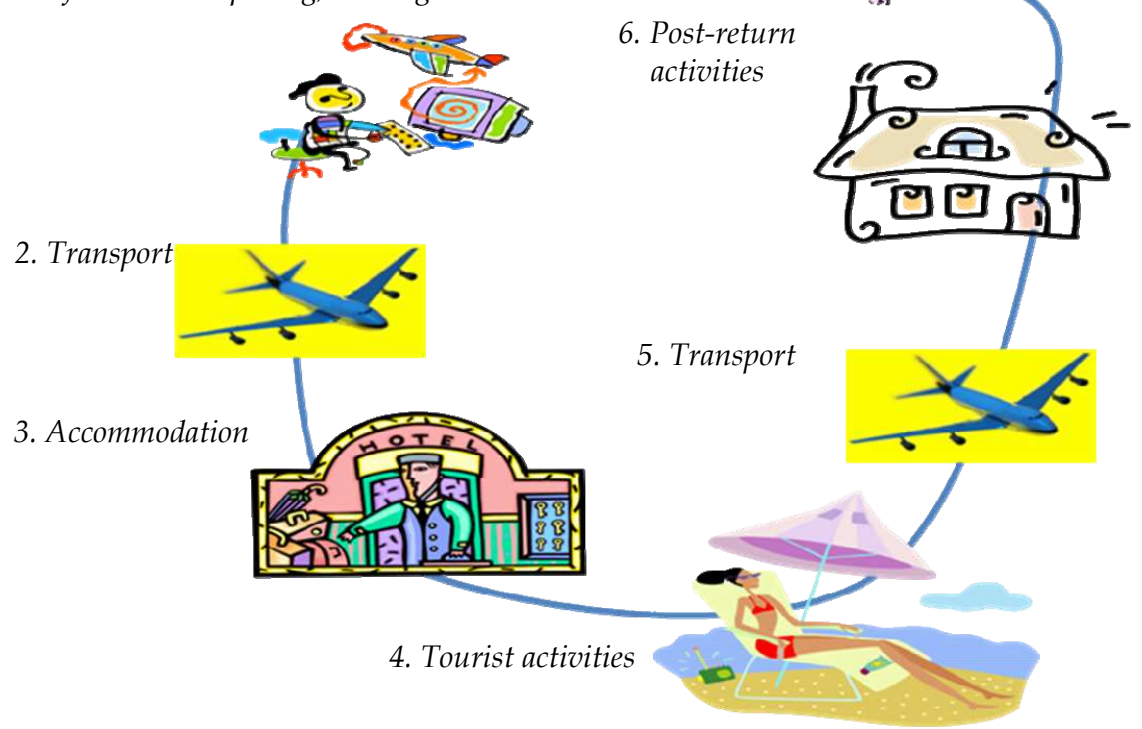

Post-return activities

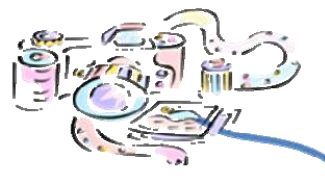

Fig. 1. Life cycle of tourist experience

When the system boundary of specific tourist products is studied individually, the following elements should be considered:

- Consumables and services needed to run the business. For example, when accommodation services are analysed, consumables such as soap, shampoo and other amenities available in the bedrooms for guests should be included in the system boundary. Moreover, supporting services such as e.g. surface cleaning, energy and water supply, and waste treatment should be also included;

\footnotetext{
${ }^{1}$ EPR focuses on products, and makes producers responsible not only for their own production stage, but also for the whole life cycle of a product. This is based on the assumption that producers have the capacity to (re)design their products to avoid or reduce the related environmental impacts (Li \& Geiser, 2004). EPR has been adopted in many OECD countries, as well as in the European Union regulation for packaging waste, end-of-life vehicles, and electrical and electronic equipment waste (Mayers, 2007).
} 
- Capital goods such as e.g. furniture and buildings (e.g. construction, operation, maintenance, demolition/renovation) should be included within the system boundary if their impact is non-negligible. For instance, data concerning the life-cycle-based GHGs emissions of hotel buildings (Floridia, 2007; Sesartic \& Stucki, 2007) suggest that the building-related environmental loads should be considered in the LCA of accommodation services;

- Those tourist products along the tourist experience life cycle (see Figure 1) on which the tourist organisation analysed may have a certain influence. For instance, transport services should be included in the system boundary when accommodation services are studied. Hoteliers, in fact, may induce their guests to reach their own structures by offering discounts when eco-friendly transport modes are chosen.

Given the large number of services and goods involved in delivering a certain tourist service, simplifications of the system boundary are often needed. Each time a system boundary is simplified by excluding some goods and services from the life cycle of the tourist product analysed, the environmental significance of the excluded unit processes should be assessed case by case by using estimations and extrapolated data.

\section{Method}

As the scope of this research was bounded to Europe, sector-specific instruments for sustainable consumption and production in the travel and tourism industry were searched by consulting:

- $\quad$ EU-founded projects (e.g. LIFE+ project registry) and linked scientific literature;

- Web-sites of networks for sustainable tourism development, such as the Tour Operators Initiative (www.toinitiative.org), Ecotrans - European Network for Sustainable Tourism Development (www.ecotrans.org), and the DestiNet portal - UN Partnership for Sustainable Development (http://destinet.eu/).

The environmental instruments and initiatives found relevant for the purpose of the research have been screened according to their focus and scope, current dissemination, and how they stand in relation to the LCA principles. On the basis of this screening review, key elements of the methodological framework used as well as limitations and envisaged improvements were detected for each instrument/initiative. Major results of this analysis are shown in the overview reported in section 6 . Potential synergies amongst instruments and initiatives were identified with the aim of coming out with a general methodological framework. Section 7 presents the results of this analysis by showing, inter alia, how a new platform enabling travellers to plan eco-friendly holidays in Europe could look like.

\section{Overview of environmental instruments and initiatives}

The following sector-specific environmental instruments and initiatives were screened because found relevant to build up a new framework for sustainable consumption and production in the travel and tourism sector.

\section{Travelife}

What it is: A sustainability management system for tour operators which includes an ecolabelling scheme to qualify tour operator's suppliers (e.g. hotel, holiday village, restaurant); 
Users: Tour operators and their suppliers: accommodation structures, restaurants, other tourist companies (e.g. providers of tourist activities, such as excursions, leisure, sightseeing, etc.);

Final stakeholder: Those tourists who use to book tourist services and whole holiday packages through tour operators and travel agencies;

Current dissemination: Pretty widespread amongst tour operators (e.g. TUI, Thomas Cook, Kuoni, First Choice, Virgin Holidays, Cosmos);

Websites: www.its4travel.com, www.travelife.eu;

Reference: Kusters, 2004;

Project funding detail: EU LIFE programme, LIFE04 ENV/NL/000661, Tour-Link project -

Demonstrating how an integrated eco-labeling and tour operating supply chain management strategy can foster sustainability in tourism;

Key limitations:

- Environmental qualification criteria of tour operator suppliers are not based on the findings of LCA studies. Therefore, there is a significant risk to qualify structures which do not actually address the main environmental hot spots;

- The transport phase has not been included in the management system;

- $\quad$ There is no GHG accounting and reporting within Travelife system;

- $\quad$ No audit is required for Travelife qualification of tour operators.

Major improvement proposals:

- Choosing the environmental criteria for qualifying tour operator suppliers by taking into account the findings of a representative number of LCA case studies;

- Suppliers of passenger transport should be included in the scope of the initiative;

- Reporting the environmental performance of the labelled services may facilitate the continuous improvement of suppliers' environmental performance;

- Tour operators should be audited in order to monitor their improvement path.

\section{EU eco-label}

What it is: Type I Environmental label (ISO 14024:1999) eco-label for accommodation structures and camp sites;

Users: Accommodation structures and campsites;

Final stakeholder: Those tourists who use to book tourist accommodation autonomously; Travel agencies and tour operators;

Current dissemination: More than 300 accommodation structures and 70 campsites have been labelled so far in the EU. In several European Countries, many tourist eco-labels different than the EU scheme have been disseminating;

Websites: http:/ / ec.europa.eu/environment/eco-label/index_en.htm, www.eco-label.com

Reference: European Commission, 2009; European Parliament, 2008;

Project funding detail: ANPA (The Italian Environmental Agency, now called ISPRA) was appointed by the European Commission; 
Key limitations:

- Even if inspired to LCA principles, no LCA study seems to have been carried out to define, validate and revise the mandatory and optional criteria of the EU Eco-label schemes;

- In several European Countries, many national based tourist eco-labels, different from the EU eco-label scheme, have been disseminating. This phenomenon, which practically represents an entrance barrier for the EU eco-label, clashes with the European harmonisation of EU standards and, therefore, with the recognisability of labels by tourists. The Visit initiative tried to overcome this limitation.

Major improvement proposal:

- Criteria of the existing EU eco-label schemes should be set up according to the findings of a representative number of LCA case studies to be conducted in the travel and tourism sector.

\section{Blue Flag}

What it is: a voluntary award for tourist destinations such as beaches and marinas;

Users: Municipalities;

Final stakeholder: Tourists;

Current dissemination: According to the Blue Flag web-site, in 2011 approximately 3650 beaches and marinas in 46 countries (across Europe, South Africa, Morocco, Tunisia, New Zealand, Brazil, Canada and the Caribbean) were awarded the Blue Flag;

Websites: www.blueflag.org ;

Reference: FEE, 2011;

Project funding detail: The Foundation for Environmental Education in Europe (FEEE) presented in 1987 the concept of the Blue Flag to the European Commission, and it was agreed to launch the Blue Flag Programme as one of several "European Year of the Environment" activities in the Community;

Key limitations:

- $\quad$ The Blue Flag seems to be a quality label rather than an environmental one because its criteria seem to be more related to quality issues;

- $\quad$ The scope is too narrow (only beaches and marinas are covered).

Major improvement proposals:

- Additional environmental criteria may be introduced by deriving the key environmental issues and drivers from a representative number of LCA case studies;

- Further schemes may be used for labelling the environmental performance of tourist resorts other than beaches and marinas.

\section{Other tourist environmental labels}

What it is: Environmental labels and declarations of tourist services. Most labels are "Type I Environmental labels" (ISO 14024:1999) and are characterised by a regional scale 
dissemination (e.g. Viabono, Legambiente Turismo, The Green Key, Milieubarometer, Ibex label, and many others);

\section{Users: Tourist accommodation structures;}

Final stakeholder: Those tourists who use to book their own holidays autonomously; Travel agencies and tour operators;

Current dissemination: slightly widespread at the regional scale;

Websites: Viabono - www.viabono.de; Legambiente Turismo - www.legambienteturismo.it; The Green Key - www.green-key.org; Milieubarometer - www.milieubarometer.nl; Ibex label - www.oe-plus.ch; and so forth.

References: Buckley, 2002; Font, 2002; Font \& Buckley, 2001; Sloan et al., 2009;

Project funding detail: Many regional scale projects have been carried out so far;

Key limitations:

- Eco-labels in the tourism industry are many and their excessive proliferation clashes with their recognisability by tourists;

- Even if inspired to LCA principles, no LCA study seems to have been carried out to define, validate and revise the mandatory and optional criteria of the eco-label schemes;

Major improvement proposal:

- Criteria of the existing environmental labels should be set up according to the findings of a representative number of LCA case studies to be conducted in the travel and tourism sector.

\section{Visit}

What it is: The Voluntary Initiative for Sustainability in Tourism (Visit) is a technical standard setting up the framework according to which credible tourism eco-labels should operate in Europe. The purpose of this initiative was, therefore, to put together tourist labeling under a unique umbrella, also to increase the label recognisability by tourists. Visit is also the name of the association which manages such a standard.

Users: Tourist accommodation structures;

Final stakeholder: Those tourists who use to book their own holidays autonomously; Travel agencies and tour operators;

Current dissemination: Twelve eco-label schemes have joined the Visit initiative so far;

Websites: www.visit21.net; www.ecotrans.org/visit/index.html;

Reference: Hamele et al., 2004;

Project funding detail: LIFE00 ENV/NL/000810, Visit project - Eco-labels for Sustainable Tourism in Europe: demonstrating how eco-labels can move the European tourism market towards sustainability;

Key limitations: 
- $\quad$ Even if the $6^{\text {th }}$ criterion of the Visit standard states that, to be qualified by Visit, a tourist eco-label has to consider product life cycle issues in setting product related criteria, it is a bit obscure how environmental hot-spots have been identified so far;

- No accreditation scheme has been defined for tourist eco-label schemes to assure competence, credibility, integrity and independence from market stakeholders.

Major improvement proposals:

- Running a significant number of LCA case studies to come up with robust criteria should become a mandatory requirement in the Visit standard;

- $\quad$ Eco-label scheme programmes should be accredited by a third party body before letting the schemes to get in Visit;

- $\quad$ More efforts are needed to make the Visit's logo more and more visible by combining the existing eco-labels with Visit's logo.

\section{TourBench}

What it is: A free European monitoring and benchmarking online tool to reduce the environmental burden and costs of tourist accommodation organisations;

Users: Hotels and campsites;

Final stakeholder: Hotels and campsites;

Current dissemination: Unknown;

Website: http://destinet.eu/tools/measurement_instruments/tb-01-en-pub.pdf;

References: Hamele \& Eckardt, 2007; Hamele \& van der Burgh, 2006;

Project funding detail: LIFE programme, LIFE03 ENV/NL/000473, European Monitor and Benchmarking Initiative for Environmental Impacts and Costs in Tourist Accommodation;

Key limitations:

- The environmental assessment stage of TourBench is not based on a Life Cycle perspective;

- The scope of TourBench is too limited, including only hotels and campsites;

- Solutions for environmental improvement are suggested to users, but neither potential providers nor related prices are included in the tool;

- No considerations on quality are associated to environmental improvement solutions, thus jeopardising traveller satisfaction.

Major improvement proposals:

- $\quad$ Broadening the TourBench scope to other tourist services and covering their entire life cycles.

\section{EcoPassenger}

What it is: A user-friendly internet tool to cross-compare energy consumption, $\mathrm{CO}_{2}$ and other airborne emissions of alternative transport modes (e.g. planes, cars and trains) for travelling all around Europe;

Users: Travellers; 
Final stakeholder: Travellers;

\section{Current dissemination: Unknown;}

Website: www.ecopassenger.com;

Reference: Knörr, 2008;

Project funding detail: Project funded by the International Union of Railways (UIC);

Key limitations:

- Even if LCA principles have been adopted, this instrument considers only the following transport modes: railway, car and airplane;

- The LCA methodology, on which EcoPassenger is based, did not include any LCA data on the following LCA phases: construction, maintenance, and disposal of infrastructures and vehicles;

- No booking is possible through the EcoPassenger's website;

- $\quad$ No link has been provided on Eco-Passenger web-site for eco-friendly tourist activities and destinations.

Major improvement proposals:

- The scope of Ecopassenger might be enlarged to additional transport modes and environmental indicators;

- Data should be in line with the European rules for LCI datasets in the ILCD Handbook (European Commission, 2010).

\section{Proposal for a new methodological framework}

To figure out if instruments are able to support each other and gain mutual benefits, potential synergies were investigated amongst: the existing sector-specific environmental instruments shown in section 6, an eco-design methodology for services (De Camillis et al., 2010c), and environmental performance-based declaration schemes (e.g. the forthcoming European Commission's Product Environmental Footprint, and the International EPD System). On this basis, a new methodological framework for sustainable consumption and production in the travel and tourism industry was developed (see Figure 2).

Key elements of this framework are:

- Revised eco-label schemes (i.e. Travelife labels, EU eco-label, other eco-labels in the Visit initiative). These labels, conceived for awarding those tourist products whose environmental performance is supposed to be more beneficial to the environment than on average due to the fulfilment of a set of criteria, are expected to be accompanied with the potential environmental performance of tourist products in terms of environmental footprint. This footprint may be calculated through an LCAbased calculator to be integrated in TourBench. Another major change concerns the procedure to derive eco-label criteria. More information are given below in the Core LCI database paragraph.

- An improved version of TourBench. In this context, the TourBench scope ideally is broadened to all travel and tourist activities, specifically transport to the destinations. In 
this way, all tourist organisations are able to quantify the environmental performance of their own tourist products in terms of environmental footprint, and to detect options for improvement by comparing the environmental performance of their own products against a benchmark representing the average environmental performance of the whole product group. This is the product environmental footprint calculator that we proposed above for eco-label assessments. If developed according to a common set of methodological guidelines, this calculator may produce data for environmental labels to compare the environmental performance of tourist products and destinations in a consistent and scientifically sound manner.

- A core LCI database. When tourist organisations calculate the environmental footprint of their own products, the TourBench calculator may be used for this purpose. This calculator is envisaged to be linked with a central LCI database. This database aims at supporting any assessment to quantify the environmental footprint for eco-labels. The core LCI database may be composed of unit processes from the ELCD database (i.e. the European Commission's LCI reference database for energy carriers, transport, and waste management) (European Commission, 2011) and from other data sources. In addition, the core LCI database is expected to include the average LCI datasets of the tourist products covered by eco-label schemes. This is also needed to provide benchmarks to TourBench. For this purpose, representative average LCI datasets per tourist product concerned are expected to be regularly calculated from those productspecific environmental performance data coming out from the TourBench calculator. To come out with average LCI datasets, data need to be documented and reviewed e.g. for issuing eco-labels. The crucial environmental aspects of a certain tourist product's life cycle (i.e. the so called environmental hot spots) can be derived by analysing the findings of the tourist product datasets from the core LCI database. These environmental hot spots may be used for coming up with scientifically sound criteria for Type I eco-labelling schemes, and for feeding eco-design processes with regard to the key environmental requirements and technical specifications. Pre-requirement to derive scientifically sound criteria are to document in depth the LCI datasets of the tourist products labelled, and to follow international LCA guidelines (European Commission, 2010).

If the changes proposed above were implemented, the newly developed methodological framework would be able to support sustainable production and consumption instruments and initiatives in the travel and tourism sector.

In particular, if Figure 2 is read from the top, tourist organisations have the potential to:

- Assess and improve the environmental performance of their own existing tourist products by using the environmental footprint calculator included in TourBench. On this basis, options for improvement may be identified and implemented. If eco-label criteria are fulfilled, the tourist products assessed can then be labelled.

- Develop novel tourist products by using an eco-design tool. This tool may be a version of TESPI (Misceo et al., 2004) adjusted to the rules of the eco-design methodology for services developed by De Camillis et al. (2010c).

If Figure 2 is read from the bottom, the sustainable consumption side of the methodological framework can be identified. In particular, a platform to plan eco-friendly holidays is 
envisaged. This instrument has the potential to help travellers in planning eco-friendly holidays "from door to door" by indicating the most environmentally-sound destinations, organisations and solutions (i.e transport modes, accommodation services and other tourist services). This might be possible if:

- The environmental footprint of package holidays can be calculated by summing up the environmental footprint figures of the tourist products that compose the holiday package (i.e. environmental footprint calculators in Ecopassenger and TourBench are combined);

- Booking platforms and web-sites add the environmental performance of tourist products to their general quality information and feedback, thus allowing users to sort out results according to their environmental performance.

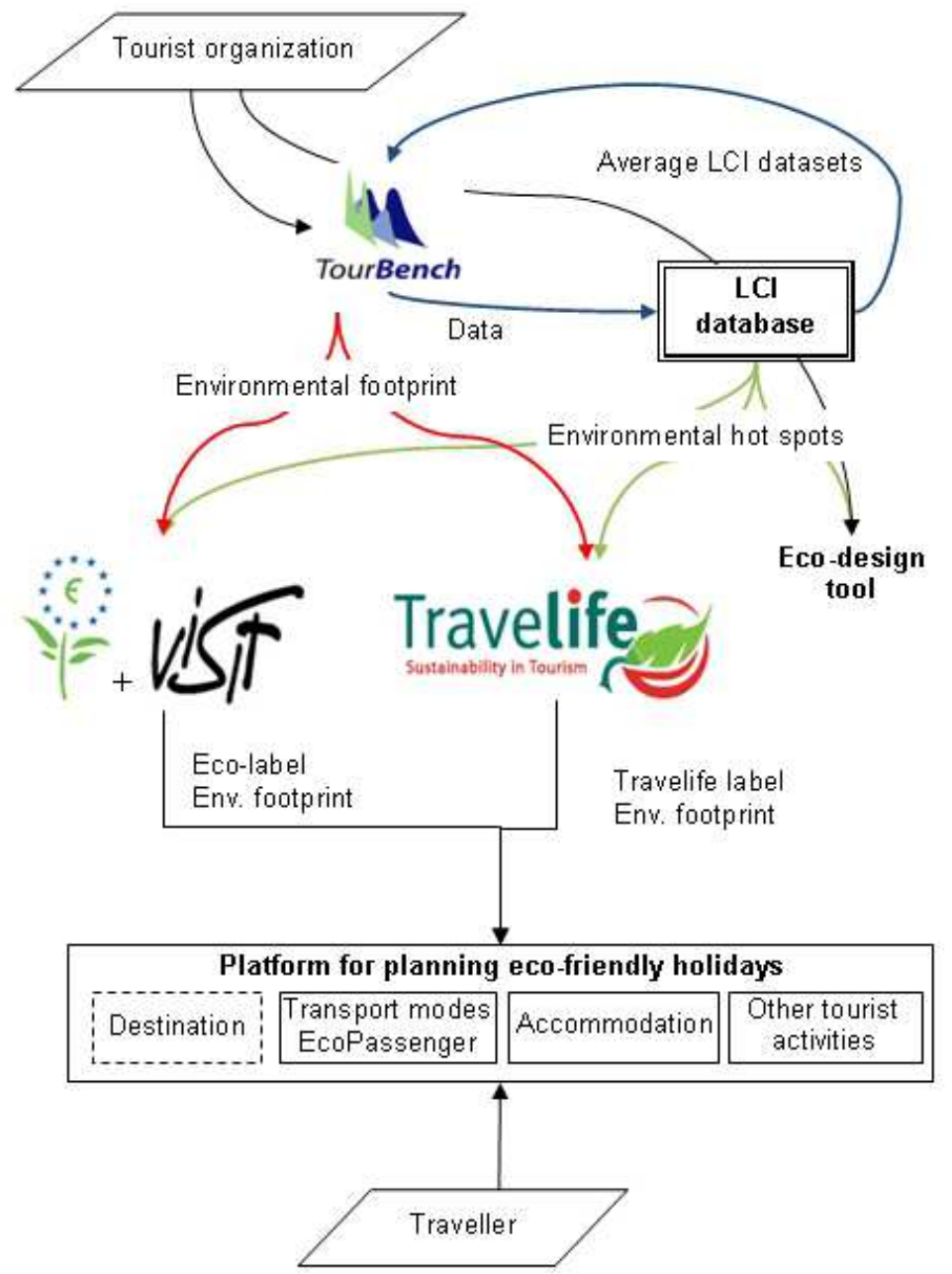

Fig. 2. A possible suite of LCA-based tools for eco-friendly holidays 


\section{Conclusion}

In this chapter we outlined a new methodological framework for sustainable consumption and production in the travel and tourism industry. This framework includes, inter alia, a proposal for a new platform enabling travellers to plan eco-friendly holidays in Europe.

Learning from the experience of the European Food Sustainable Consumption and Production Round Table co-chaired by the European Commission and food supply chain partners (Peacock et al., 2011), significant improvements of sustainable production and consumption can be achieved if key stakeholders are equally involved in developing and fine-tuning a harmonised framework methodology for the assessment and communication of the environmental performance of products. A similar initiative would be advisable for the travel and tourism industry because the on-going proliferation of environmental assessment methodologies and communication tools has the potential to confuse or even mislead travellers and other stakeholders.

Integration of instruments, synergies among initiatives and general consensus across supply chain partners on methodological and communication aspects are needed to come out with consistent and stronger measures for sustainable consumption and production in the travel and tourism industry.

\section{References}

Azapagic, A. \& Clift, R. (1999). Life cycle assessment and multiobjective optimisation. Journal of Cleaner Production Vol. 7, No. 2, pp. 135-143.

Becken, S. \& Hay, J.E. (2007). Tourism and Climate Change: Risks and Opportunities, Channel View Publications, Clevedon, UK.

Bramwell, B. \& Lane, B. (2008). Priorities in Sustainable Tourism Research. Journal of Sustainable Tourism, Vol. 16, No. 1, pp. 1-4.

Buhalis, D. \& Laws, E. (2001). Tourism Distribution Channels: Practices, Issues and Transformations, Continuum International Publishing Group, London, UK.

Chadwick, R.A. (1994). Concepts, definitions, and measures used in travel and tourism research, in: J.R.B. Ritchie and C.R. Goeldner (ed), Travel, Tourism, and Hospitality Research: a Handbook for Managers and Researchers, pp. 65-80, John Wiley \& Sons, New York, NY, USA.

Chambers, T. (2004). Environmental Assessment of a mass tourism package holiday and a responsible tourism package holiday, using Life Cycle Assessment and Ecological Footprint Analysis. Master of Science Thesis, Environmental Sciences, University of East Anglia, Norwich, UK.

Corsico, S. (2007). Adattamento della metodologia LCA all'analisi e valutazione degli impatti generati dal turismo: un caso di studio. Final Degree Thesis, Scienze Ambientali, D. Pitea (supervisor), Università degli Studi Milano-Bicocca, Milan, Italy.

De Camillis, C., Petti, L. \& Raggi, A. (2008). LCA: a key-tool for Sustainable Tourism? Proceedings of the 8th International Conference on EcoBalance. Tokyo, Japan, 10-12 December 2008, pp. 485-488. 
De Camillis, C., Raggi, A. \& Petti, L. (2010a). Tourism LCA: state-of-the-art and perspectives. The International Journal of Life Cycle Assessment, Vol. 15, No. 2, pp. 148-155.

De Camillis, C., Raggi, A. \& Petti, L. (2010b). Life Cycle Assessment in the framework of sustainable tourism: a preliminary examination of its effectiveness and challenges. Progress in Industrial Ecology, An International Journal, Vol. 7, No. 3, pp. 205-218.

De Camillis, C., Raggi, A. \& Petti, L. (2010c). Ecodesign for services: an innovative comprehensive method. International Journal of Sustainable Economy, Vol. 2, No. 3, pp. 277-292.

De Camillis, C., Raggi, A. \& Petti, L. (2010d). Environmental labelling: definition of product categories in the travel and tourism industry. Proceedings of the Scientific Workshop of the Italian Network on LCA "La metodologia LCA: approccio proattivo per le tecnologie ambientali. Casi studio ed esperienze applicative", Padua, Italy, 22 April 2010, pp. $173-$ 181.

Debbage, K.G. \& Daniels, P. (1998). The tourist industry and economic geography: missed opportunities, in Ioannides, D.\& Debbage, K. (ed.) The Economic Geography of the Tourist Industry: A Supply-side Analysis, pp. 17-30, Routledge, New York, NY, USA.

EPD (2011). The International Environmental Product Declaration (EPD) System, Sweden. URL: www.evirondec.com

European Commission (2003). Integrated Product Policy. COM (2003) 302 final.

European Commission (2007). Carbon Footprint - what it is and how to measure it. European Platform on LCA Newsletter. European Platform on LCA, Joint Research Centre, Ispra, Italy.

European Commission (2008). Sustainable Consumption and Production Action Plan (SCP). COM (2008) 397 final.

European Commission (2009). Commission Decision of 9th July 2009 establishing the ecological criteria for the award of the Community eco-label for tourist accommodation service, Official Journal of the European Union, L 198, pp. 57-79.

European Commission (2010). International Reference Life Cycle Data System (ILCD) Handbook, European Commission, Joint Research Centre (JRC), Institute for Environment and Sustainability (IES), Ispra, Italy.

European Commission (2011). Reference European Life Cycle Data System (ELCD) core database version II, Accessed in October 2011, URL:

http:/ / lca.jrc.ec.europa.eu/lcainfohub/datasetArea.vm

European Parliament (2008). Regulation (EC) No 1980/2000 of the European Parliament and of the Council of 17 July 2000 on a revised Community eco-label award scheme, Official Journal of the European Union, L 237, pp. 1-12.

FEE (2011). Blue Flag 2011, Foundation for Environmental Education, Copenhagen, Denmark.

Finnveden, G., Hauschild, M.Z., Ekvall, T., Guinée, J., Heijungs, R., Hellweg, S., Koehler, A., Pennington, D. \& Suh, S. (2009). Recent developments in life cycle assessment. Journal of Environmental Management, Vol. 91, No. 1, pp. 1-21.

Fitzgerald, D.P., Herrmann, J.W., Sandborn, P.A., Schmidt, L.C. \& Gogoll, T.H. (2007). Design for Environment (DfE): Strategies, Practices, Guidelines, Methods, and 
Tools, in Kutz, M. (ed.) Environmentally Conscious Mechanical Design, Wiley, London, UK, pp. 1-24.

Floridia, D. (2007). Studio delle metodologie di Life Cycle Assessment applicate al servizio turistico: il caso di una struttura ricettiva di Abano-Montegrotto. Final Degree Thesis, Scienze Ambientali, D. Pitea (supervisor), Università degli Studi MilanoBicocca, Milan, Italy.

Font, X. (2002). Environmental certification in tourism and hospitality: progress, process and prospects. Tourism Management, Vol. 23, No. 3, pp.197-205.

Font, X. \& Buckley, R. (2001). Tourism Ecolabelling: Certification and Promotion of Sustainable Management, CABI Publishing, New York, NY, USA.

Gössling, S., Peeters, P. M., Ceron, J. P., Dubois, G., Patterson, T. \& Richardson, R. B. (2005). The eco-efficiency of tourism. Ecological Economics, Vol. 54,No. 4, pp. 417- 434.

Graburn, N.H.H. (2004). The anthropology of tourism, in S. Williams (ed.), Tourism: Critical Concepts in the Social Sciences, pp. 91-112, Routledge, New York, NY, USA.

Graedel, T.E. (1997). Life-cycle assessment in the service industries. Journal of Industrial Ecology, Vol. 1, No. 4, pp. 57-70.

Grießhammer, R., Benoît, C., Dreyer, L.C., Flysjö, A., Manhart, A., Mazijn, B., Méthot, A. \& Weidema, B.P. (2006). Feasibility Study: Integration of Social Aspects into LCA, United Nations Environment Program, Society of Environmental Toxicology and Chemistry Life Cycle Initiative, Freiburg, Germany.

Hamele, H. \& Eckardt, S. (2007). Environmental Initiatives by European Tourism Businesses: Instruments, Indicators and Practical Examples, Ecotrans, Saarbrücken, Germany Universität Stuttgart, Stuttgart, Institute for Energy Research (IER), Germany.

Hamele, H. \& van der Burgh, R. (2006). TourBench: Monitoring and Benchmarking of Environmental Consumption and Cost in Tourist Accommodation Services, Ecotrans, Saarbrücken, Germany - Universität Stuttgart, Stuttgart, Institute for Energy Research (IER), Germany.

Hamele, H., Haas, E., Kusters, N., Hammerl, M., Proctor, J., Pils, M., Vitali, P., Diwok, D., Wendenbaum, M., Kuitert, K. \& Ouwehand, M. (2004). The VISIT Initiative: Tourism Eco-labelling in Europe - Moving the Market towards Sustainability, Ecotrans, Saarbrücken, Germany.

Hauschild, M.Z., Dreyer, L.C. \& Jørgensen, A. (2008). Assessing social impacts in a life cycle perspective-Lessons learned. CIRP Annals-Manufacturing Technology, Vol. 57, No. 1, pp. 21-24.

Heijungs, R., Guinée, J.B., Huppes, G., Lankreijer, R.M., Udo de Haes, H.A., Wegener Sleeswijk, A., Ansems, A.M.M., Eggels, A.M.M., van Duin, R. \& de Goede, H.P. (1992). Environmental Life-Cycle Assessment of Products: Guide and Backgrounds, Centre for Environmental Science, Leiden, The Netherlands.

Heiskanen, E. (2002). The institutional logic of life cycle thinking. Journal of Cleaner Production, Vol. 10, No. 5, pp. 427-437.

Hunkeler, D. (2006). Societal LCA methodology and case study. International Journal of Life Cycle Assessment, Vol. 11, No. 6, pp. 371-382.

Hunkeler, D. \& Rebitzer, G. (2005). The future of life cycle assessment. The International Journal of Life Cycle Assessment, Vol. 10, No. 5, pp. 305-308. 
Hunter, C. \& Shaw, J. (2007). The ecological footprint as a key indicator of sustainable tourism, Tourism Management, Vol. 28, No. 1, pp. 46-57.

Jørgensen, A., Le Bocq, A., Nazarkina, L. \& Hauschild, M. (2008). Methodologies for social life cycle assessment. The International Journal of Life Cycle Assessment, Vol. 13, No. 2, pp. 96-103.

Judd, D.R. (2006). Commentary: Tracing the commodity chain of global tourism. Tourism Geographies, Vol. 8, No. 4, pp. 323-336.

Kloepffer, W. (2008). Life cycle sustainability assessment of products. The International Journal of Life Cycle Assessment, Vol. 13, No. 2, pp. 89-95.

Knörr, W. (2008). EcoPassenger: environmental methodology and data, Ifeu - Institut für Energieund Umweltforschung Heidelberg GmbH, Heidelberg, Germany.

Krozer, Y. (2008). Life cycle costing for innovations in product chains. Journal of Cleaner Production, Vol. 16, No. 3, pp. 310-321

Kusters, N. (2004). Demonstrating how an integrated ecolabeling and tour operating supply chain management strategy can foster sustainability in tourism, LIFE04 $\mathrm{ENV} / \mathrm{NL} / 000661$.

Leiper, N. (2008). Why 'the tourism industry' is misleading as a generic expression: The case for the plural variation, 'tourism industries'. Tourism Management, Vol. 29, No. 2, pp. 237-251.

Lew, A.A., Hall, C.M. \& Williams, A.M. (2004). A Companion to Tourism, Blackwell Publishing, Oxford, UK.

Li, L. \& Geiser, K. (2004). Environmentally responsible public procurement (ERPP) and its implications for integrated product policy (IPP). Journal of Cleaner Production, Vol. 13, No. 7, pp. 705-715.

Maxwell, D., Sheate, W. \& van der Vorst, R. (2006). Functional and systems aspects of the sustainable product and service development approach for industry, Journal of Cleaner Production, Vol. 14, No. 17, pp. 1466-1479.

Mayers, K. (2007). Strategic, financial, and design implications of extended producer responsibility in Europe: a producer case study. Journal of Industrial Ecology, Vol. 11, No. 3, pp. 113-131.

McCrory, P. (2006). Take nothing but pictures, leave nothing but footprints...? British Journal of Sports Medicine, Vol. 40, No. 7, pp. 893-894.

Middleton, V.T.C. (1989). Tourist product, in S.F. Witt \& L. Moutinho (ed.), Tourism Marketing and Management Handbook, pp. 573-576, Prentice-Hall, Hemel Hempstead, UK.

Misceo, M., Buonamici, R., Buttol, P., Naldesi, L., Grimaldi, F. \& Rinaldi, C. (2004). TESPI (Tool for Environmental Sound Product Innovation): a simplified software tool to support environmentally conscious design in SMEs. Proceedings of SPIE Environmentally Conscious Manufacturing IV, 26-27 October 2004, SPIE-The International Society for Optical Engineering Vol. 5583, Philadelphia, Pennsylvania, USA, pp. 186-192.

Norris, G.A. (2001). Integrating life cycle cost analysis and LCA. The International Journal of Life Cycle Assessment, Vol. 6, No. 2, pp. 118-120. 
Peacock, N., De Camillis, C., Pennington, D., Aichinger, H., Parenti, A., Brentrup, F., Raggi, A., Rennaud, J., Sára, B., Schenker, U., Unger, N. \& Ziegler, F. (2011). Towards the Harmonised Framework Methodology for the Environmental Assessment of Food and Drink Products. The International Journal of Life Cycle Assessment, Vol. 16, No. 3, pp. 189-197.

Peeters, P., Gössling, S. \& Lane, B. (2009). Moving towards low-carbon tourism: New opportunities for destinations and tour operators, in Gössling, C.M. Hall \& D.B. Weaver (ed.), Tourism Futures: Perspectives on Systems, Restructuring and Innovations, pp 240-257, Routledge, New York, USA.

Pennington, D.W., Potting, J., Finnveden, G., Lindeijer, E., Jolliet, O., Rydberg, T. \& Rebitzer, G. (2004). Life cycle assessment Part 2: Current impact assessment practice. Environment International, Vol. 30, No. 5, pp. 721-739.

Petti, L. \& Tontodonati, S. (2002). The use of LCA as a tool to implement EPDs: an application to hotel services. Proceedings of the 5th International Conference on EcoBalance, Tsukuba, Japan, 6-8 November 2002, pp. 329-332.

Raggi, A. \& Petti, L. (2006a). A newly developed integrated environment-quality approach for the design of hotel services. Progress in Industrial Ecology, An International Journal, Vol. 3, No. 3, pp. 251-271.

Raggi, A. \& Petti, L. (2006b). Life Cycle Assessment and tourism services, In: Workshop "Stato dell'arte e prospettive degli studi di Life Cycle Assessment in Italia", Bologna, 18 October 2006, accessed: 20 November 2011, URL: http://www.reteitalianalca.it/larete/workshop-2006/atti

Raggi, A., Sára, B, \& Petti, L. (2005). Life Cycle Assessment case studies in small and medium sized enterprises offering tourist accommodation services, Proceedings of the 12th SETAC Europe LCA Case Studies Symposium, Bologna, Italy, 10-11 January 2005, pp. 171-174.

Raggi, A., Bruzzi, L. and Bordin, A. (2008a). The Italian LCA Network: objectives and activities of the Working Group on Tourist Services. 8th International Conference on EcoBalance. Tokyo, Japan, pp. 489-492.

Raggi, A., Petti, L., De Camillis, C., Bordin, A. and Boatto, T. (2008b). LCA dei prodotti turistici: stato dell'arte e prospettive. $2^{\circ}$ Workshop della Rete Italiana LCA "Sviluppi dell'LCA in Italia: percorsi a confronto". Pescara, Italy, pp. 63-76.

Rebitzer, G. \& Buxmann, K. (2005). The role and implementation of LCA within life cycle management at Alcan. Journal of Cleaner Production, Vol. 13, Nos. 13-14, pp. 13271335.

Rebitzer, G., Ekvall, T., Frischknecht, R., Hunkeler, D., Norris, G., Rydberg, T., Schmidt, W.P., Suh, S., Weidema, B.P. \& Pennington, D.W. (2004). Life cycle assessment Part 1: Framework, goal and scope definition, inventory analysis, and applications. Environment International, Vol. 30, No. 5, pp. 701-720.

Rebitzer, G. \& Hunkeler, D. (2003). Life cycle costing in LCM: ambitions, opportunities, and limitations. The International Journal of Life Cycle Assessment, Vol. 8, No. 5, pp. 253256.

Rebitzer, G. \& Seuring, S. (2003). Methodology and application of life cycle costing. The International Journal of Life Cycle Assessment, Vol. 8, No. 2, pp. 110-111. 
Romeril, M. (1989). Tourism and the environment--accord or discord? Tourism Management, Vol. 10, No. 3, pp. 204-208.

Rosenblum, J., Horvath, A. \& Hendrickson, C. (2000). Environmental implications of service industries. Environmental Science and Technology, Vol. 34, No. 22, pp. 4669-4676.

Scott, D., Peeters, P., \& Gössling, S. (2010). Can tourism deliver its "aspirational" greenhouse gas emission reduction targets? Journal of Sustainable Tourism, Vol. 18, No. 3, pp. 393 $-408$.

Sesartic, A. \& Stucki, M. (2007). How climate efficient is tourism in Switzerland? An assessment of tourism's carbon dioxide emissions in relation to its added value, Diploma Thesis, Imboden \& S. Perch-Nielsen (supervisors). ETH, Zurich, Switzerland.

Consoli, F., Allen, D. Boustead, I., Fava, J., Franklin, W., Jensen, A.A., de Oude, N., Parrish, R., Perriman, R. Postlethwaite, D., Quay, B., Seguin J. \& Vigon, B. (1993). Guidelines for Life Cycle Assessment: a code of practice. SETAC Press, Sesimbra, Portugal, and Pensacola, USA.

Sisman, K. (1994). A life-cycle analysis of a holiday destination: Seychelles. British Airways environment report, Cambridge, UK.

Sloan, P., Legrand, W., Tooman, H. \& Fendt, J. (2009). Best practices in sustainability: German and Estonian hotels, in Chen, J.S. (ed.), Advances in Hospitality and Leisure, Vol. 5, pp 89-107, Emerald Group Publishing Limited, Bingley, UK.

Spengler, T. \& Stolting W. (2008). Life cycle costing for strategic evaluation of remanufacturing systems. Progress in Industrial Ecology, An International Journal, Vol. 5, No. 1, pp. 65-81.

Tapper, R. \& Font, X. (2004). Tourism supply chains. Report of a desk research project for The Travel Foundation. Leeds Metropolitan University and Environment Business \& Development Group, Leeds, UK.

Ujma, D. (2001). Distribution channels for tourism: theory and issues, in Buhalis, D., \& Laws, E. (ed.), Tourism Distribution Channels: Practices, Issues and Transformations, pp. 3352, Continuum International Publishing Group, London, UK.

UK CEED (1998). An assessment of the environmental impacts of tourism in St. Lucia. British Airways Environment Report 5:98, Cambridge, UK.

UNEP (2009). Guidelines for social life cycle assessment of products, UNEP/SETAC Life Cycle Initiative, UNEP, Paris, France.

UNWTO (2010). Tourism Highlights (2010 Edition), United Nations World Tourism Organization, Madrid, Spain.

UNWTO (2008). Tourism Market Trends (2007 Edition - World Overview), United Nations World Tourism Organization, Madrid, Spain.

UNWTO UNEP WMO (2008). Climate Change and Tourism: Responding to Global Challenges, United Nations World Tourism Organization, Madrid, Spain.

Vezzoli, C. \& Sciama, D. (2006). Life Cycle Design: from general methods to product type specific guidelines and checklists: a method adopted to develop a set of guidelines/checklist handbook for the eco-efficient design of NECTA vending machines. Journal of Cleaner Production, Vol. 14, Nos. 15-16, pp. 1319-1325. 
Weidema, B.P. (2005). ISO 14044 also applies to Social LCA. The International Journal of Life Cycle Assessment, Vol. 10, No. 6, p. 381. 


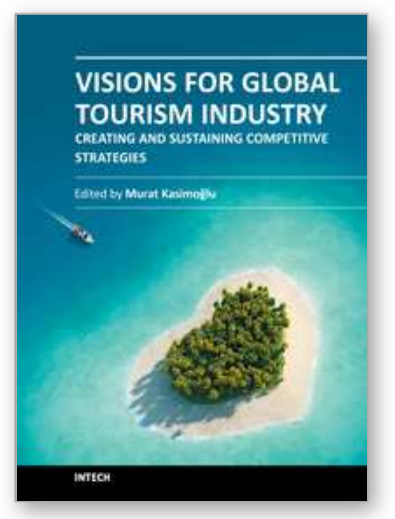

\section{Visions for Global Tourism Industry - Creating and Sustaining Competitive Strategies}

Edited by Dr. Murat Kasimoglu

ISBN 978-953-51-0520-6

Hard cover, 478 pages

Publisher InTech

Published online 18, April, 2012

Published in print edition April, 2012

We have been witnessing huge competition among the organisations in the business world. Companies, NGO's and governments are looking for innovative ways to compete in the global tourism market. In the classical literature of business the main purpose is to make a profit. However, if purpose only focus on the profit it will not to be easy for them to achieve. Nowadays, it is more important for organisations to discover how to create a strong strategy in order to be more competitive in the marketplace. Increasingly, organisations have been using innovative approaches to strengthen their position. Innovative working enables organisations to make their position much more competitive and being much more value-orientated in the global tourism industry. In this book, we are pleased to present many papers from all over the world that discuss the impact of tourism business strategies from innovative perspectives. This book also will help practitioners and academician to extend their vision in the light of scientific approaches.

\section{How to reference}

In order to correctly reference this scholarly work, feel free to copy and paste the following:

Camillo De Camillis, Paul Peeters, Luigia Petti and Andrea Raggi (2012). Tourism Life Cycle Assessment (LCA): Proposal of a New Methodological Framework for Sustainable Consumption and Production, Visions for Global Tourism Industry - Creating and Sustaining Competitive Strategies, Dr. Murat Kasimoglu (Ed.), ISBN: 978-953-51-0520-6, InTech, Available from: http://www.intechopen.com/books/visions-for-global-tourismindustry-creating-and-sustaining-competitive-strategies/tourism-life-cycle-assessment-lca-a-newmethodological-framework-for-sustainable-consumption-and-pro

\section{INTECH}

open science | open minds

\section{InTech Europe}

University Campus STeP Ri

Slavka Krautzeka 83/A

51000 Rijeka, Croatia

Phone: +385 (51) 770447

Fax: +385 (51) 686166

www.intechopen.com

\section{InTech China}

Unit 405, Office Block, Hotel Equatorial Shanghai

No.65, Yan An Road (West), Shanghai, 200040, China 中国上海市延安西路65号上海国际贵都大饭店办公楼405单元

Phone: +86-21-62489820

Fax: +86-21-62489821 
(C) 2012 The Author(s). Licensee IntechOpen. This is an open access article distributed under the terms of the Creative Commons Attribution 3.0 License, which permits unrestricted use, distribution, and reproduction in any medium, provided the original work is properly cited. 